\title{
人工内耳の子音処理
}

$\begin{array}{llll}\text { 庄司 } & \text { 和彦・楖原 } & \text { 淳二・藤田 } & \text { 修治* } \\ \text { 大森 } & \text { 孝一・伊藤 } & \text { 壽一・巟嶋 久剛 } \\ \text { 本庄 箃 } & & & \end{array}$

\section{Simulation of Consonants with a Multi-electrode Cochlear Implant}

\author{
Kazuhiko Shoji, Junji Sakakihara, Koichi Omori, \\ Juichi Ito, Hisayoshi Kojima and Iwao Honjo \\ (Kyoto University) \\ Syuji Fujita \\ (Osaka Red Cross Hospital)
}

While patients with multi-electrode cochlear implants can distinguish vowels well, it is hard for them to recognize consonants, especially voiceless plosives. To find out why they are not able to distinguish the three voiceless plosives $/ \mathrm{p} /, / \mathrm{t} /, / \mathrm{k} /$, we examined the simultaneous electrical pulses of each electrode of a cochlear implant with the input of the consonant-vowel syllables $/ \mathrm{pa} /, / \mathrm{ta} /, / \mathrm{ka} /$ in detail, using a computer and an analogdigital converter. The rate of electrical pulses caused by the voiceless plosives was lower than that caused by vowels. The intensity of electrical pulses was similar. And then we synthesized sounds which simulated the consonant-vowel syllables with multi-electrode cochlear implants. Each synthesized sound was so different from normal syllables that we could not recognize them as consonant-vowel syllables. The results show that more information of consonants must be translated through a cochlear implant for better recognition of consonants.

Key words : cochlear implants, deaf patient, simulation of consonants

はじめに

我々は，1987年より現在までに㰍および高度 感音難聴者 7 例に, Nucleus 社製の多チャンネ ル型人工内耳を使用し，良好な成績を得た。な かでも母音弁別の成績は良好で，22個の電極全 てを蝸牛内に插入しえた 6 症例のうち, 術後の リハビリテーションが完了した 4 症例では母音
弁別率はほぼ90\%に達した。乙れはこの人工内 耳のフォルマント抽出方式が，母音の弁別に有 効であるととを示すあのといえる.

しかし，子音の弁別は母音に比して劣ってお り, confusion matrix test では最良の症例でも弁 別率は約 $50 \%$ で，特に無声破裂音 $/ \mathrm{p} /, / \mathrm{t} /, / \mathrm{k} /$ の弁別はほとんど不能であった。 
との理由を検討する一つの方法として，まず 人工内耳に無声破裂音が入力された時の電極の 発火状況を記録し，これに基づきコンピュータ で波形を合成し，乙れを聴力正常者が聴取し， 人工内耳患者が「聴取」していると考えられる 無声破裂音の聴覚判定を行った。とうして無声 破裂音の弁別が人工内耳装用者でどの程度可能 であるかを調べた。

\section{方 法}

\section{1）発火電極の記録}

まず Nucleus 社製22チャンネル人工内耳の スピーチプロセッサを，ある人工内耳埋め込み 患者と同一設定下においた。この患者では，電 極はひとつ拈きの双極で使用し，300〜 4000 Hz の周波数帯域を 20 亿分割し，乙れを1〜20の電 極に割り当てて，電極ひとつおきの双極間に通 電するように設定されていた，乙の患者では全 ての電極が蝸牛の基底回転に挿入されており， 各電極に相当するおよその特徽周波数を，レン トゲン所見に基づき $100 \mathrm{~Hz}$ 単位で決定した。 次に図 1 に示すブロックダイアグラムで, DAT（ディジタルオーディオテープレコーダ） に録音して抢いた成人男性の子音音節 $/ \mathrm{pa} /$, $/ \mathrm{ta} /, \mathrm{ka} /$ を再生して人工内耳にライン入力し, 各電極の発火を音声と同時に AD 変換してコ

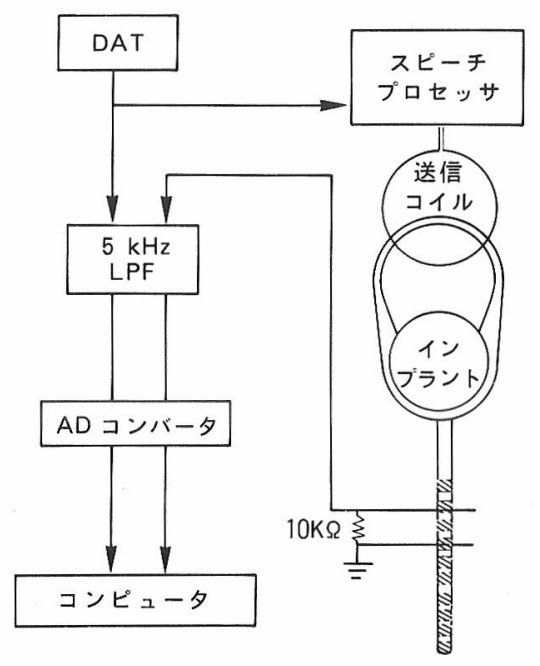

図 1 発火電極記録のためのブロックダイアグラム
ンピュータに入力し，どの電極がどのようなタ イミングで発火したかを正確に調べた.

サンプリング周波数は $10 \mathrm{kHz}$ で，分解能は 12 ビットである。図 2 亿使用した音節のサウン ドスペクトログラムを示す。 / pa/, / ta/, / ka/, の持続時間はそれぞれ $267 \mathrm{msec}, 273 \mathrm{msec}, 251$ msec であり，その無声破裂音部は $/ \mathrm{p} /, / \mathrm{k} /$ が $30 \mathrm{msec}, / \mathrm{t} /$ は $22 \mathrm{msec}$ であった.

2）合成音の作成

次に，選択された電極の挿入位置に対応する 特徴周波数からなる持続時間 $5 \mathrm{msec}$ のトーン バースト波形をコンピュータで作成し，それを 発火のタイミングと一致させて配置し，シミュ レーション波形を合成した。単一電極の発火に 対しては単一周波数のサイン波からなるトーン バーストを対応させたが，ほとんどの場合は $1 \mathrm{msec}$ のタムラグで 2 つの電極の発火がみ られ，乙れには各電極位置に相当する特徵周波 数のサイン波を同位相で加算した波形のトーン バーストを使用した．同一の電極では刺激電圧 がほぼ同一であったのでトーンバーストの振幅 は一定とした。図 3 に/pa/の/a/ の持続部

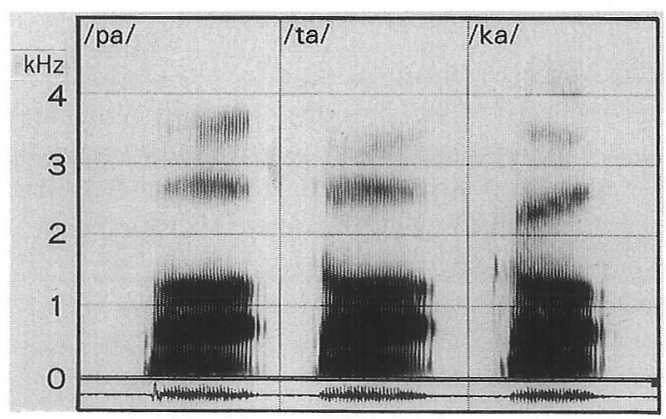

図 2 使用した音節のサウンドスペクトログラム

\section{音声波形}

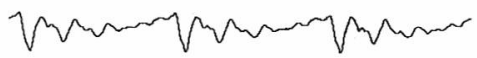

13 番電極

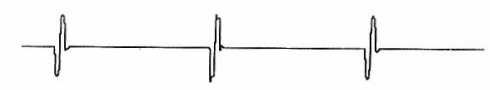

16 番電極

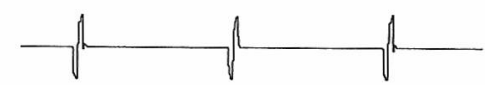

合成波形

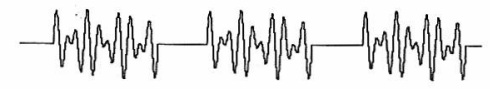

図 3 発火電極と合成波形の対応 
分の音声波形と 13 番と 16 番の 2 つの電極でみら れた発火，抢よび各電極に相当する特徴周波数 $2000 \mathrm{~Hz}, 1400 \mathrm{~Hz}$ のサイン波を加算したトーン バーストを同一時間軸上に示す。波形の合成に 使用したプログラムは C 言語 (Turbo C $\mathrm{C}^{\mathrm{TM}}$ ) で 記述した。

波形の再生には 16 ビット DA コンバータを 用い，サンプリング周波数 $20 \mathrm{kHz}$ でアナログ 信号に変換し，カットオフ周波数 $10 \mathrm{kHz}$ のス ムージングフィルターを通した後, $125 \mathrm{kHz}$ ま での周波数特性を持ち，過渡特性が最も良好 な高域用スピーカー（テクニクス EAS-10 TH $800^{\mathrm{TM}}$ ) で再生した。

記録および波形の合成に使用したコンピュー タは PC-9801UX41 (NEC 社製)で, AD コンバ ータは ADX-98TM, DA コンバータは DAX $98^{\mathrm{TM}}$, 波形処理ソフトは WAVE MASTER ${ }^{\mathrm{TM}}$ で，いずれあカノープス社製である。サウンド スペクトログラムには Apple 社の Macintosh П ${ }^{\mathrm{TM}}$ と音響分析ソフト Mac $\operatorname{Adios}^{\mathrm{TM}}$ とを利 用した。

\section{結果}

図 4 は各子音音節が入力された際の発火電極 を時間軸上にプロットしたあのである./ka/で は $/ \mathrm{k} /$ に相当する時間内に発火した電極はな く，電極11が最初に発火したのは起声から44.1 $\mathrm{msec}$ 後であった. / t/ では $2 つ, / \mathrm{p} /$ では $3 つ$ の電極の発火が，各子音に相当する時間帯で認 められたに過ぎなかった。また，起声から最初 の電極発火までの時間は, / t/ では $15.6 \mathrm{msec}$, /p/では $15.0 \mathrm{msec}$ を要した。乙の遅れは人工 内耳での処理時間と考元られ，無声破裂音の持 続時間プラス約 $15 \mathrm{msec}$ の間に発火した電極が, この人工内耳で無声破裂音の情報を伝えるすの と仮定すると, /p/ では $7 つ, / \mathrm{t} /$ では $6 \supset, / \mathrm{k} /$ では 2 つの電極の発火がみられた. しかし，乙 の数は後続母音の発火頻度に比して明らかに少 なく，また，その電気刺激の強さを母音部でも 発火のみられた $/ \mathrm{pa} /$ の 17 番電極の発火電圧之 比較した所，その比は1.01であり，子音部で特
に低い電圧ではないととがわかった。

$/ \mathrm{p} /, / \mathrm{t} /, / \mathrm{k} /$ での発火電極の違いは，図 2 で みられる無声破裂部のエネルギー分布の違いを ある程度反映しており，特に/t/における7番 電極の発火は / p/, / k/ ではみられない 2700 $\mathrm{Hz}$ 付近のエネルギーによると推定される.

図 2 で明らかなように，各子音音節で後続母 音の第 1 , 第 2 フォルマント周波数はほぼ同じ であり，かつ，経時的な変化がほとんどないに あかかわらず，人工内耳で発火する電極は各子

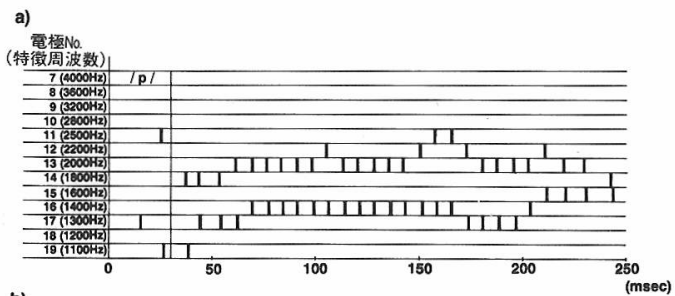

b)
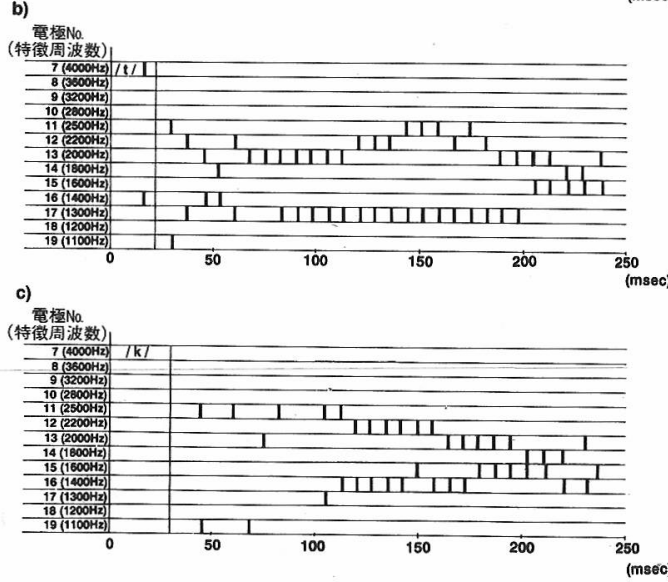

図 4 a ）は $/ \mathrm{pa} /$, b ）は $/ \mathrm{ta} /$, c ）は $/ \mathrm{ka} /$ が入力 された時の発火電極

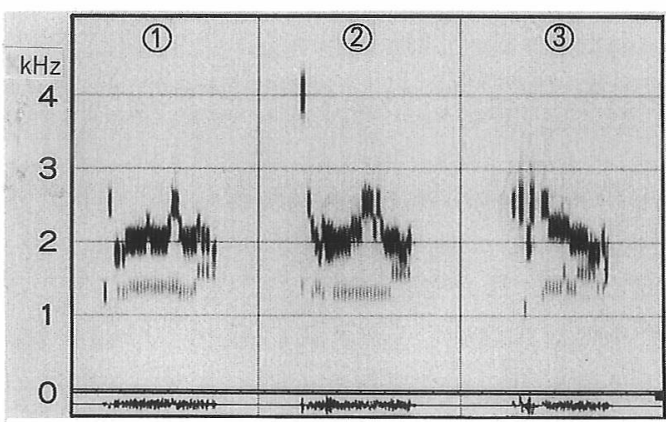

図 5 合成音のサウンドスペクトログラム 
音音節で異なっており，また，同一の子音音節 であってあ，後続母音の部分で経時的に異なる 電極の発火が認められた。なお，発火の頻度は 基本周波数に一致していた。 $/ \mathrm{pa} /, / \mathrm{ta} /, / \mathrm{ka} /$ をシミュレートした再生音のサウンドスペクト ログラムを図 5 に示す。 スピーカーの周波数特 性のため, $1.5 \mathrm{kHz}$ 以下の音圧はやや低くなっ ているが，フォルマント周波数は図 4 で示した 発火電極の特徵周波数之のほぼ完全な一致が確 認される.

これらの合成音の聴覚印象では，むとの音声 $/ \mathrm{pa} /, / \mathrm{ta} /, / \mathrm{ka} /$ とは大きく異なって抢り, 破 裂音であるととの認識あ不可能であった，各合 成音相互間の区別は困難ながらも可能であり， これは母音相当部の違いによるものと思われた.

\section{考按}

現在, 多チャンネル方式の人工内耳は 2 方 式に分類できるが1)，我々が使用している Nucleus 社製の人工内耳ではフォルマント抽出 方式 ${ }^{2)}$ を採用しており，各母音の第 1 ，第 2 フ オルマント周波数を検出し, これに応じて刺激 電極を選択し，基本周波数の頻度で電極を発火 させて母音のフォルマント情報を伝える方式で ある．挿入電極の位置が蝸牛の基底回転に限局 されるため，発火電極の位置の特徴周波数が害 際の母音のフォルマント周波数より高い方にず れるにあかかわらず，母音の弁別が良好である 事は, 先に逆フーリエ変換によって線形な合成 音を作成して行なった母音のシミュレーショ ン3) で，5母音間の弁別が容易であったてとか ら理解できる.

しかし人工内耳埋め込み患者の子音の弁別, 特に無声破裂音の弁別は極めて不良であった.

人工内耳での電極の発火を調べ，てれに基づく 人工内耳患者「聴取」音のシミュレーションを 行うことは，乙の様な子音の弁別が悪い原因を 探る上で，またとの不良な弁別を改善する上で 有用な手段であると考えられる.

子音をシミュレートする際，発火電極が様々 で, しかす発火の間隔が一様でないために, 線
形な合成波形によるシミュレーションは困難で， そのため電極の発火にトーンバーストを対応さ せる方法をとった. しかし, 蝸牛内での電気刺 激の範囲が正確には判定できないこと文，有毛 細胞から聴神経につたえられる刺激と電流によ る神経末端の刺激の違いが音声認識にどう影響 するか不明であること，などから，今回の子音 の再現が完璧とはいい難いのは母音の場合と同 様である. しかし，乙の方式の人工内耳が蝸牛 の place theory に基づいている以上，今回のよ うな処置法は合理的であり，シミュレートした 音と患者の聴取音との間には一定の近似がある あのと考えられる.

さて今回の検討で, 無声破裂音の情報が人工 内耳装用者の内耳に充分に伝えられていない事 が確認されたが，乙の理由としてまず，乙の Nucleus 社製人工内耳が発火頻度を音声の基 本周波数の抽出で決定しているため，基本周波 数の検出ができない無声音では電極の発火回数 が少なくなる事があげられる，次に，乙の人工 内耳では音の強さの情報は電気刺激の強さで伝 えているとされている4) にもかかわらず，先の 測定結果でみられた様に電気刺激の強さが無声 部と有声部とで差異がなく, 子音と母音の音 圧の差の情報が伝えられていないものと考えら れた.

また，各子音音節の母音部分のフォルマント 周波数に相当する発火電極に変動がみられたの は, 本人工内耳のフォルマント周波数の検出処 理の方法になお問題があるととを示すすのと考 えられた。

子音の情報をいかに多く正確に伝えるかが， 将来の人工内耳の最大の課題と考えられるが, その際，今回のような合成音によるフィードバ ックが極めて有用であると考えられる。

\section{まとめ}

Nucleus 社の人工内耳では，無声破裂音に一 致する電極の発火頻度が少ないこと，また，発 火電圧む母音部と差がないことが確認された。 また，無声破裂音音節をシミュレ・乬した音の 
聴取で, $/ \mathrm{pa} /, / \mathrm{ta} /, / \mathrm{ka} /$ 相互の弁別は困難であ った. 以上の所見より，乙の方式の人工内耳で は無声破裂音の情報は充分に伝えられていない 事が明らかとなった。

\section{参考文献}

1) 伊藤壽一：人工内耳について. 耳鼻臨床 $81: 779$ $\sim 786,1988$.

2) Clark GM and Dewhurst DJ : A multipleelectrode hearing prosthesis for cochlear implantation in deaf patients. Med Progr Technology $5: 127 \sim 140,1977$.
3) 庄司和彦, 藤田修治, 大森孝一, 他 : 人工内耳聴 取音のシミュレーション. 耳鼻臨床 $81 ： 1709$ 1713, 1988.

4) Clark GM, Blamey PJ, Brown AM, et al : The University of Melbourne-Nucleus Multi-electrode Cochlear implant. Advances in Oto-RhinoLaryngology 38 (ed by Pfaltz CR). pp 63 84, Karger, Basel, 1987.

$$
\left(\begin{array}{l}
\text { 原稿採択 : 平成元年 } 5 \text { 月 } 25 \text { 日 } \\
\text { 別刷請求先 : 呪嶋久剛 } \\
\text { T606 京都市左京区聖護院川原町 } 54 \\
\text { 京都大学医学部耳男喵喉科学教室 }
\end{array}\right)
$$

